\title{
Rehabilitation nursing care and emancipatory process
}

Cuidado em enfermagem de reabilitação e processo emancipatório

Atención de enfermería de rehabilitación y proceso de emancipación

Soraia Dornelles Schoeller ${ }^{1}$

(D) https://orcid.org/0000-0002-2822-4407

Maria Manuela Ferreira Pereira da Silva

Martins $^{2}$

(D) https://orcid.org/0000-0003-1527-9940

Flavia Regina de Souza Ramos ${ }^{1}$

(D) https://orcid.org/0000-0002-0077-2292

Caroline Porcelis Vargas ${ }^{1}$

(i) https://orcid.org/0000-0002-9904-0816

Milena Amorim Zuchetto

(D) https://orcid.org/0000-0002-6042-8733

Daniella Karine de Souza Lima

(D) https://orcid.org/0000-0001-7167-0907

${ }^{1}$ Federal University of Santa Catarina,

Florianópolis, Santa Catarina, Brazil

${ }^{2}$ Nursing School of do Porto, Porto, Portugal

Correspondence author:

Soraia Dornelles Schoeller

E-mail: soraia.dornelles@ufsc.br

Received: 07.11.19

Accepted: 27.04 .20

\section{Abstract}

Background: The science of nursing is immersed in the process of care, and, historically speaking, the profession was built based on scientific criteria of what care is and how to practice it. This study explores how to practice nursing care as an emancipatory process.

Objective: This article aims to share and stimulate the debate about nursing care and emancipatory process, using Honneth's theory of recognition and Bloch's principle of hope.

Main topics under analysis: Reflection on the theory of recognition and principle of hope as conceptual foundations for rehabilitation nursing care. Study based on philosophical literature about rehabilitation. Nursing care is considered an intersubjective relationship in the emancipatory process, in which the self-realization of the nurse depends on the self-realization of the cared-for person.

Conclusion: The construction of the subject occurs in intersubjective, historical, and recognition relationships. For responsible care, we should consider the three levels of recognition: love, rights, and solidarity. In this sense, the care will be an integral and emancipatory process.

Keywords: rehabilitation nursing; hope; philosophy, nursing

\section{Resumo}

Enquadramento: A ciência da enfermagem está imersa no processo de cuidar, e, historicamente, a profissão foi construída com base em critérios científicos sobre o que é e como cuidar. Este estudo pretende questionar como se pratica o cuidado de enfermagem enquanto processo emancipatório.

Objectives: Este artigo tem como objetivo compartilhar e estimular o debate sobre cuidados de enfermagem e processo empancipatório, usando a teoria do reconhecimento de Honneth e o princípio da esperança de Bloch.

Principais tópicos em análise: Reflexão sobre a teoria do reconhecimento e dialética da esperança como fundamentos conceituais para o cuidado de enfermagem na reabilitação. Baseado na literatura filosófica contextualizada na reabilitação. Para isso, o cuidado de enfermagem é considerado uma relaçáo intersubjetiva num processo emancipatório, no qual a autorrealização do enfermeiro depende da autorrealização da pessoa cuidada.

Conclusão: A construção do sujeito ocorre em relações intersubjetivas, históricas e de reconhecimento. Para o cuidado responsável, devemos considerar os três níveis de reconhecimento: amor, direitos e solidariedade. Assim, o cuidado será um processo emancipatório e integral.

Palavras-chave: enfermagem de reabilitação; esperança; filosofia em enfermagem

Resumen

Marco contextual: La ciencia de la enfermería está inmersa en el proceso de atención, e históricamente la profesión se construyó con base en criterios científicos de lo que es y cómo atender. Lo que se cuestiona en este estudio es cómo ejercer la atención de enfermería como proceso de emancipación. Objetivo: Este artículo pretende compartir y estimular el debate sobre la atención de enfermería y el proceso de emancipación, utilizando, para ello, la teoría del reconocimiento de Honneth y la dialéctica de la esperanza de Bloch.

Principales temas en análisis: Reflexión sobre la teoría del reconocimiento y la dialéctica de la esperanza como fundamentos conceptuales de la atención de enfermería en la rehabilitación. Estudio basado en la literatura filosófica en la rehabilitación. La atención de enfermería se considera una relación intersubjetiva en un proceso emancipador, en el que la autorrealización del enfermero depende de la autorrealización de la persona atendida.

Conclusión: La construcción del sujeto tiene lugar en relaciones intersubjetivas, históricas y de reconocimiento. Para una atención responsable, debemos considerar los tres niveles de reconocimiento: amor, derechos y solidaridad. Así, la atención será un proceso integral y emancipador.

Palabras clave: enfermería de rehabilitación; esperanza; filosofía en enfermería
How to cite this article: Schoeller, S. D., Martins, M. M., Ramos, F. R., Vargas, C. P., Zuchetto, M. A., \& Lima, D. K. (2020). Rehabilitation nursing care and emacipation proccess. Revista de Enfermagem Referência, 5(2), e19084. doi:10.12707/RIV19084 


\section{Introduction}

Nursing is the science, art, and profession of care. It is socially necessary, carried out by qualified people, is represented by entities that establish rules for practice, and has a specific field of knowledge, with clear parameters on who can or cannot practice it. Historically speaking, the nursing profession has been built as a result of the establishment of this field of knowledge and practice, based on scientific criteria of what therapeutic care is and how to perform it (Alligood, 2013).

Several theories address nursing care. Scholars and professionals have been debating the fundamentals, the purpose and the way of implementing care and, since the days of Nightingale theories or theoretical models of nursing, they address the therapeutic care and the premises necessary for its implementation (Alligood, 2013).

Our proposal for developing this debate is to look at this relationship of care based on Axel Honneth's theory of intersubjective and social recognition. This is considered the third-generation representation of the Frankfurt School, renown for having established the critical theory. Honneth investigates the problems in the current capitalist society, from an intersubjective perspective. A fundamental concept for comprehending the beginning of relationships and social conflicts and understanding the evolution of societies makes up the core of his "intersubjective and social recognition" theory (Fuhrmann, 2013, p. 79).

This article is the result of years of reflection in three concurrent areas: clinical practice of rehabilitation nursing, ethics and bioethics in health, and philosophy in nursing. It counted on the participation of three research groups in two countries. It aimed to reflect on dimensions necessary to care in nursing rehabilitation and suggest elements to build a theoretical-philosophical matrix that determines the implementation of this care, based on the theory of recognition of Axel Honneth as well as on the principle of hope of Ernst Bloch. A parallelism is established between these theories and rehabilitation nursing care as an emancipatory process of the subjects involved. This theoretical reflection points to a theoretical framework that substantiates studies developed in partnership by researchers from two universities, one in Brazil and another in Portugal (Federal University of Santa Catarina - UFSC; Nursing School of Porto - ESEP).

This study is presented in three parts, arranged better to express the understanding of the authors on the subject and not because of its importance. The first part addresses theoretical-philosophical elements established in the studies of Axel Honneth and Ernst Bloch, considered essential for rehabilitation nursing care as an emancipatory process. These authors point out important aspects in consideration of a more plastic care, which assumes that the subjects involved in this relationship (nurse and disabled person) are historical beings who recognize and reaffirm (or do not) themselves in dynamics concrete, social, and historical relationships.

The second part deals with the dimensions necessary to the nursing care process and the subjects involved in this relationship. The following dimensions were defined: the current historical moment; the paradigm shift from healing to good living; globalization and its everyday consequences; and the care relationship involving people who live this globalized historical moment.

As for the third part, the link between the first two is established in an attempt to describe theoretical elements related to care as an emancipatory process. In this sense, reflections carried out in the studies of the aforementioned authors are correlated with a summary of premises necessary for the construction of this process.

This was a first step toward the object of study, and one of the main reasons for its publication is to share and stimulate the debate about nursing care for the autonomous care of subjects, a concept to be developed throughout this research.

\section{Development}

Axel Honneth's theory of recognition addresses aspects considered relevant to rehabilitation care by the researchers of this study, which will be detailed below. Honneth develops his theory based on Hegel's discussion (philosophy) and Mead's (social psychology) on recognition as one of the central notions of relationships between people (Honneth, 1995).

Honneth considers the absence of intersubjective and social recognition, or disrespect, as the cause of contemporary social conflicts. He believes that it is possible to explain the dynamics of social transformations and conflicts based on the injustice and disrespect that result from the abuse inflicted to the attempts of individual and social recognition (Honneth, 1995).

The centrality of relationships is removed in simply material or economic inequality (Hartmann \& Honneth, 2006). This is a result of the experiences in the processes of identity formation. The construction of the subject takes place in intersubjective relations, at three levels of recognition: love, rights and solidarity, as shown further below (Honneth, 1995).

The subject can only know himself/herself through the objective accomplishment of his/her own intentions (which occurs primarily through intersubjective relationships), meaning that a purely cognitive dimension is abandoned so the individual can assume a state of practical knowledge of himself/herself. The relations between subjects determine the development of each one (Miranda, 2011). The subject, when recognized in his/her abilities and qualities, is recognized by the other subject of the relationship, with whom he/she reconciles. Also, the subject eventually discovers his/her own identity and becomes something particular, contrasting with the other subject (Honneth, 1995).

The social reality is woven by recognition relationships, which are historical and can be broken when people are deprived of the conditions necessary to acquire respect. Recognition is the basis of the establishment and accomplishment of collective and individual goals (Honneth, 1995). One subject, when relating to another, provokes in himself/herself a reaction similar to the stimulus it caused, and, in this constant and dynamic (re)learning of one another, both develop themselves as subjects (Honneth, 1995). Thus, language (which is also social and historical) is essential. Through these relationships, each subject manages to become conscious of his/her own identity. "A subject can only acquire a consciousness of itself to the extent to which it learns to perceive its own action from the symbolically represented second-person perspective" (Honneth, 1995, p. 75). The relationship of recognition results from a demarcation of the relationship, of the spaces and actions as a dialectical counterpoint to 
the delimitation of the relationship, of the spaces, and of the actions. In this sense, the level of a love relationship is essential and confers essential elements to nursing care. Recognition begins in the spheres of more private and intimate relationships, moving gradually onto a more general and collective context, forming a set of attitudes of the individuals involved in the process. Therefore, recognition involves the generalization of social standards of conduct. Thus, when speaking of recognition, we can assume that the participation of an individual in his/ her community comes from the internalization of the generalized other, leading to a relationship of reciprocal recognition. In this sense, recognition is the self-understanding of a person who has learned to see the perspective of the generalized other as the self-understanding of a collective person (Honneth, 1995).

Love relationships are considered primary relationships: friendship, sentimental bonds, and especially family. In this context, people recognize themselves as needy individuals, united in mutual dependence due to necessity. This bond depends on the bodily existence of the other and is nurtured by feelings of affection and appreciation. The very first representation of this bond is the mother/ child relationship, in a constant equilibrium "between symbiosis and self-assertion" (Honneth, 1995, p. 98).

According to the theory, the self-confidence of each depends on the safety of the love of the other. Love represents "a symbiosis refracted by mutual individuation" (Honneth, 1995, p. 107) and liberation for independence must be supported by the trust of the continuity of dedication and love of the other. In love relationships, the experience of ensuring continuity of love, even when subjects become independent of one another, must be mutual, and subjects can recognize themselves as independent and continue to be loved beings. Therefore, recognition can be characterized as a double process, as subjects become free but are still emotionally attached to the beloved subject (Honneth, 1995).

The logic of love is the balance between the demarcation of the subject with its individuation and (de)limitation and closer relationships. It should be noted that this level of recognition results in self-confidence for future participation in public life, and "it is only this symbiotically nourished bond, which emerges through mutually desired demarcation, that produces the degree of basic individual self-confidence for autonomous participation in public life" (Honneth, 1995, p. 107).

The mechanism of legal recognition is similar to that of love, but it is founded on the right of equality and the generalized other. It is based on the notion that an individual can understand himself/herself as a subject of rights and know his/her obligations to the other, also as a bearer of rights. Thus, we are rights-bearing people when we take the perspective of the other and understand it and recognize it, as a being different from ourselves but with moral obligations like ourselves. We understand that we are also subjects with rights and are recognized as members of a mutual relation to meet our needs (Honneth, 1995). This form of recognition is historically established and relates to respect. Any person should value it with a view to equality, for which he/she was made subject to legal rights, assuming that he/she can decide rationally on moral issues. It is based on the moral imputability of all members of a society, in which legitimacy depends on a rational agreement between people in a situation of equality. It is a process in which the right of a morally responsible person has gradually increased, as, "under pressure from struggles for recognition, evernew prerequisites for participation in rational will-formation have to be taken in consideration" (Honneth, 1995, p. 114-15).

The legal person has three statutes. The negative, meaning that the state cannot intervene in his/her freedom, and the positive right of public participation and positive right in the distribution of fundamental goods. The right allows the person to form in himself/herself the consciousness of being able to respect oneself because he/she deserves the respect of others. The moral responsibility of the person to respect himself/herself and others can only be assumed with the establishment of universal human rights. For this purpose, it is necessary to create conditions so that individual rights are guaranteed to all subjects as free persons, and not only based on their status as a member of a particular social group (Honneth, 1995).

According to Honneth, "only then will the individual legal person be able to see in them an objectivated point of reference for the idea that he or she is recognized for having the capacity for autonomously forming judgements" (Honneth, 1995, p. 119).

Thus, respect, and dialectically the self, is the principle of legal recognition.

The level of recognition entitled solidarity refers to individual abilities and cultural status, which values the various private properties and personal differences differently. Social worth refers to what every subject has different from others. Therefore, cultural transformations also lead to a change in appreciation parameters which came to signify "the measure of esteem that individuals are socially accorded for their individual accomplishments and abilities" (Honneth, 1995, p. 126).

Honneth (1995) relates the work to recognition because the Organization and the appreciation of social work play a central role in the structure of the recognition of a society, meaning the social appreciation that the subject receives for his/her profession.

This dimension is always tension-filled and subject to conflict, therefore, it "lends the associated form of recognition the character of an asymmetrical relationship between biographically individuated subjects" (Honneth, 1995, p. 127). Asymmetrical or unequal relationships imply a power relationship of one over another, resulting in lack of recognition, or disrespect.

However, under advanced ethical conditions, this level implies a symmetrical social relationship between autonomous subjects, with important abilities for the collective experience. They are solidarity relationships in which affection plays a part because each one will be valued by their singular characteristics that benefit the collective, achieving common goals (Spinelli, 2016).

Solidarity relations are symmetrical relationships involving the esteem of the subjects, where they appreciate, based on their values, the abilities and traits of the other as being meaningful, with a view to sharing praxis. These relationships are cases of solidarity because they create more than passive tolerance for the individuality and particularities of the other subject (Honneth, 2003).

Bloch's Principle of Hope is a philosophical perspective providing a profound explanation of the parallelism of human creation, involving social, subjective, plural, concrete, objective, and collective issues. It addresses the rupture of intellectual satisfaction and offers a critical, reflective and creative proposition of hope, provoking a dialectical thought that respects the dynamic and fertility 
of interpretations, as well as the dialectical transformations of the world, promoting a particular experience of the principle of hope as a certainty of a possible human solution (Bloch, 2005).

The principle of hope is understood as a springboard for consciousness and willingness to create, consolidating its dynamic into the step that represents the end of a beginning, affirming itself in temporal, sustaining action. In this context, hope has roots in the past that give it content and meaning, but it presents itself in a continuous updating process, without ignoring the future, and working as a communicator of promises to build a future reality (Bloch, 2005).

This phenomenon, originated from the willingness to make something imaginary possible, allowing for the reflection and intervention without an intermediary, aiming at the future, promoting the anticipation of the desire expressed in the wait, understands that desire is the raw material of hope because without desire hope would possess no content, hope would be empty. But the reverse also exists: without hope, desire would be blind, with no perspective or correct direction (Bloch, 2005). Rehabilitation nursing differs from the traditional nursing approach as care aims at rehabilitation, creating spaces of decision and proactivity related to the needs of the person in rehabilitation in different dimensions so that he or she can live a full life, even if different from others. Unlike generalist nursing whose practice is related to caring for the other, rehabilitation nursing transcends this care, aiming at the capacity of the subject to build (together with the rehabilitation nurse) tools for his/her autonomy and independence, managing strategies to promote self-care and self-control, in a logic of personand family-centered care (Rocha, Avila, \& Bocchi, 2016), with a view to a good life.

The reciprocal and intersubjective experience of self-confidence, based on the bond between professional and person in rehabilitation and his/her family, is built on the responsible and mutual recognition of nurse professional achievement based on the care provided (Risjord, 2013). Moreover, specialized care is based on mutual and reciprocal freedom and invests in collective appreciation through dignity and mutual respect, evidencing the political and social role of rehabilitation nursing (Sena, Bastos, Marques, \& Silva, 2018).

Rehabilitation nursing acts as a booster of the subject's potential. This leap of faith stimulates and promotes emancipation optimistically and creatively, aiming at the elaboration of feasible strategies and achievable objectives, based on personal needs and desires (Paula \& Amaral, 2019).

\section{Some dimensions of the process of care}

This reflection on rehabilitation nursing care should consider some dimensions related to the care process and the subjects involved in this care relationship. The first dimension concerns the historical, social, and cultural moment in which this care is performed, demonstrating various ways to live. As important as the geographical location where the care relationship occurs is the time, meaning the historical moment, not the day of the week or the hour. The historical moment is social, collectively build, reflecting the social, economic, and cultural relationships established to build the survival of the collective person and the person him/herself. Consequently, the moment determines proper interpretations of what is health, illness, and care itself. The person is the portrait of his/her historical time and his/her relations, with all the associated contradictions (Fernández Férnandez, García Martínez, \& García Martínez, 2015).

There has been a continuous debate on technological advances and changes in the epidemiological and demographic profile, characterized by a longer life, with more physical limitations and different types of chronic-degenerative diseases. People with diseases that until recently implied a closed prognosis of death or little time to live, today, when provided with the necessary health care, despite some limitations, can live well and for much longer. Today, care is as, if not more, important as the cure, which inflects the very understanding of what is health-disease process and cure of illnesses. In this sense, care assumes a central role, and the cure ceases to be the first purpose of health care practice (Aciem, \& Mazzotta, 2013).

Hence the need for new approaches to the conceptions of health practice, even questioning the biological model, materialized in the patient's body and centered on the figure of the physician who heals because it does not respond as efficiently to the historical, social, cultural, and technical needs. It also highlights the need for interdisciplinary work, which addresses the subject of integral care, collaborating for good living, and not more merely healing. It impacts nursing practice, which is the historical profession of care, especially the care of the other in activities of daily living, without considering the cure as an essential fact (Schoeller et al., 2018).

From the tradition of the perspective and the unique performance of the biological body to heal it, the vision of the other needs to be considered, being a subject of care, from his/her historical, cultural and social moment, inserted specifically into also historical, social, economic, and cultural reality. It is not enough for health professionals to handle the subject carefully as if he or she were a passive object of manipulation and extirpation of evil. Health professionals and the people in need of care should work together, in search of new parameters and actions with a view to a good life. Moreover, this process should be centered on the cared-for person because he or she has the power to transform his/her life, while health professionals are only its facilitators (Fernández Fernández et al., 2015).

Another important issue to be considered in this dimension is related to globalization, in which different understandings of the health-disease process, health care and technologies and what is good living are more closely associated and exchanged than a while ago. This is how the different cultures manifest themselves more, and the exchange of ideas is more dynamic and broadened, supported by the advancement in communications, with a rapid dissemination rate. Nowadays, information is disclosed to the entire world, in real time, regardless of where it occurs (Mendes, Nunes, Pinho, \& Gonçalves, 2018). The whole world can be accessed from the mobile phone or laptop, infiltrating our homes, seemingly stripping several cultures, allowing for greater knowledge and approximation of people. The more we contact people around the world, the more we understand and manage to relate to their habits and cultures, which can generate many questions about how strong this relationship is, whether it really exists and whether we are similar or equal people. We may ask, "But, how closely related are we? Are people across the globe all the same kind of being? If we are the same, what makes us the same? Is there a 
common humanity?” (Whelton, 2015, p. 29). We add: How much do we know about their identity?

The construction of the subject and his/her subjectivity should be under the principle of these dimensions. This is the subject for whom nursing is proposing to care. A subject of a web of complex, dramatic, and long-lasting relationships and information; "a thinking being, in a living body" (Taylor, 2014, p. 8).

On the other hand, nursing care only exists within the personal relationship between at least two subjects: the nurse and the person in need of care. When they meet, each of these two people brings these dimensions to the relationship, in which the self-realization of one depends on the self-realization of the other, regardless of the position that he or she occupies in the relationship. Thus, the relationship established between nurse and person in need of care is "reciprocal recognition and self-realization" (Melo, 2013, p. 34).

A nurse is also a thinking person in a living body, the result of relationships as complex as the cared-for subject's and when the two meet, each one comes with baggage that is the result of his/her history. This meeting would transform the lives of both, even if imperceptibly. It is, therefore, an active, non-passive relationship in which one receives and the other gives. Because an active relationship implies the exchange of experiences between two thinking beings in a biological body, living in a real historical and cultural society (or in the same, or in different societies). They are beings different from each other, and the self of one depends on the self of the other. Consequently, it is above all an intersubjective relationship to share parts of the self.

These reflections allow the following question: What are the foundations for building a rehabilitation nursing care relationship based on these dimensions: love, rights, and solidarity?

\section{Essential elements for care}

When addressing care, some central issues for this care should be considered: rehabilitation nursing care is an emancipatory process, whose purpose is the well-being of the people involved - professionals, disabled persons and their families. This process of intersubjective recognition has three dimensions: love, rights and solidarity, sustained by Axel Honneth's theory of recognition. For instance, Figure 1 demonstrates the relationship between the health professional and cared-for person.

It is a process centered on a historically, socially, culturally, and economically determined time and place. Therefore, the dimensions of recognition are concrete, as well as the construction of the subjects involved in the relationship; It is carried out between embodied intersubjectivities, also originating from a historical, social, cultural and economically determined time and place. One of the principles is the recognition of the differences between the subjects of the process and, based on this recognition, the joint construction of the process. The disabled person is a temporal, spiritual, biological, cultural, economic space unit. The nurse is a temporal, spiritual, biological, cultural, economic space unit. This relationship is pervaded by contradictions, both logical and historical. Logic, related to the deviance and the norm. Historical, related to the contingent, surroundings where each of those involved in the relationship lives. This relationship, as an emancipatory process of both involved, should be of mutual aid and solidarity, with successive periods of demarcation and approximation, always based on confidence (Wernet, Mello, \& Ayres, 2017).

A process with a time " 0 " (beginning) and a time in the future. Care should start with the diagnosis, with a "diagnosis of the present time oriented towards and by emancipation" (Melo, 2013, p. 21) Time 0 relates to the first contact between the nurse and the cared-for person, taking place in the nursing consultation.

Time " 0 " should be the result of dissatisfaction with the present of all involved in the process, and this dissatisfaction (hope) is the motive of the deviance. The process has hope as an essential element. It happens in a dialectical relationship between a health professional and a disabled person, in which the dissatisfaction with the current situation is contradicting and conflict-generating. The good living, as a result of the process, is part of the self of each subject involved, and, the self of one depends on the self of the other; in this sense, each subject involved in the relationship becomes responsible for some individual issues and mutual recognition.

Figure 1 symbolizes the process of care and the relationship between the caring subject and the cared-for subject, based on the three points introduced by Axel Honneth, namely: self-confidence-love, self-respect-rights and valorization-solidarity. All this built on the Andreas of each. This means that each subject already enters the relationship with a process of prior recognition, according to his/her own social history and is the embodiment of this process.

Although recognition levels are the same for both, indi-

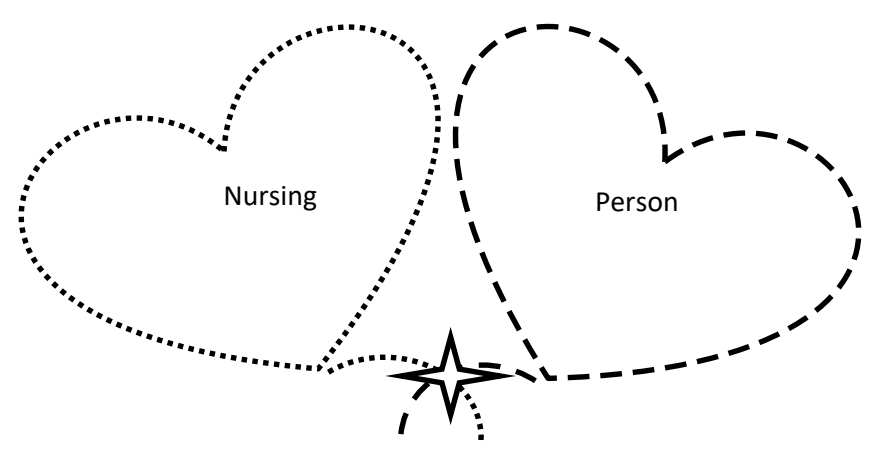

Figure 1. Graphical representation of the relationship between health professional and cared-for person, based on Axel Honneth's theory of recognition. 
vidual and collective experiences of each person result in different insertions in, and visions of, the world. These differences are the foundation of the relationship itself, as this allows sharing the experiences and will transform each person involved, reinforcing or denying itself, modifying it inexorably.

Care as an emancipatory process for good living implies the autonomy of the participants in this process. It is based on the self of each, where nurse and cared-for person, through the intersubjective relationship of recognition for love, respect and solidarity rebuild their individual and joint lives, as shown by Figure 2.

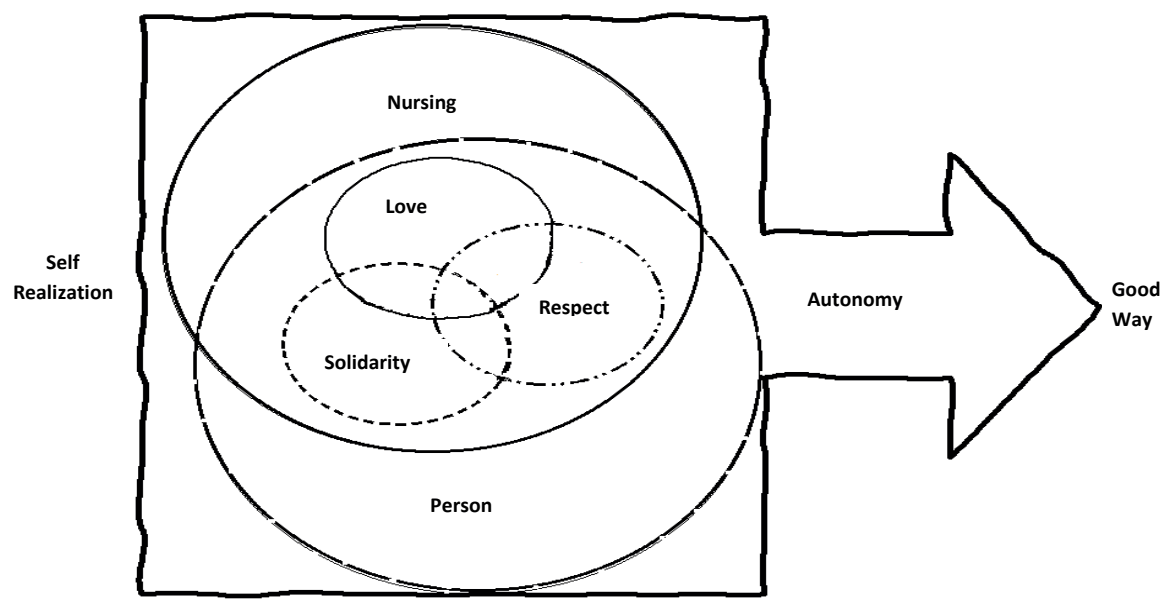

Figure 2. Graphic representation of the process of care as an emancipatory process.

\section{Conclusion}

This reflection has in consideration the Axel Honneth's recognition theory and Ernst Bloch's principle of hope, to describe dimensions and principles for rehabilitation nursing care.

The construction of the subject happens in intersubjective, historical, and recognition relationships at the three following levels: love, rights, and solidarity. Nursing care is achieved between two beings who establish recognition relationships with demarcation and delimitation, in which the self of one depends on the self of the other. In this sense, Honneth provides the best way to think about this relationship of care. It is especially interesting when it comes to rehabilitation, in which the process is necessarily dependent on the will of the cared-for person. Rehabilitation requires partnership, and the nurse cannot manipulate the other, for it is the other who should empower himself/herself and his/her reality to (re)build ways of living well.

When discussing rehabilitation nursing care, one must consider the recognition of social rights, bonds of affection, and solidarity to be consolidated between the disabled person and his/her relationships - the emancipatory process of the subject. This study reflects on the need for a historical notion in the rehabilitation process, sustaining care on a common and realistic goal adapted to the context and environment, toward a full life. When rehabilitation is also regarded as a way to promote optimism and consistency, reciprocal and mutual relations are strengthened, thus cementing the spheres of trust, respect, and social esteem.

In this sense, the implications of these theories for care practice and scientific literature include the resulting advances for the nursing profession because there is a need to debate care in the present and in the necessary historical determinations. The inception of rehabilitation requires partnership, and the nurse cannot manipulate the other because it is the other who should empower himself/herself and his/her reality to (re)build ways of living well.

\section{Author contributions}

Conceptualization: Schoeller, S. D.

Data curation: Schoeller, S. D.; Ramos, F. R. S.; Vargas, C. P.; Zuchetto, M. A.

Methodology: Schoeller, S. D.; Martins, M. F. P. S.

Writing - original draft: Schoeller, S. D.; Martins, M.F. P. S.; Vargas, C. P.; Zuchetto, M. A.

Writing - review and editing: Schoeller, S. D.; Vargas, C. P.; Zuchetto, M. A.

\section{References}

Aciem, T. M., \& Mazzotta, M. J. (2013). Personal and social autonomy of visually impaired people who were assisted by rehabilitation services. Revista Brasileira de Oftalmologia, 74(4), 261-267. doi:10.1590/S0034-72802013000400011.

Alligood, M. R. (2013). Nursing theory: Utilization \& application (5th ed.). Greenville, NC: Elsevier.

Bloch, E. (2005). Princípio da Esperança I. (1th. ed.). Rio de Janeiro, Brasil: Counterpoint.

Fuhrmann, N. (2013). Fighting to be recognition: thoughts about Axel Honneth's theory and the origins of social conflicts. Barbarói, (38), 79-96. Retrieved from http://pepsic.bvsalud.org/scielo. php?script=sci_arttext\&pid=S0104-65782013000100006\&l$\mathrm{ng}=\mathrm{pt} \& \mathrm{t} \operatorname{lng}=\mathrm{pt}$

Fernández Férnandez, M., García Martínez, A. C., \& García Martínez, M. J. (2015). Un siglo cuidando a la sociedad: Centenario del reconocimiento oficial de la enfermería en españa ( $5^{\circ} \mathrm{ed}$.). Cantabria, España: Colegio de Enfermería de Cantabria. 
Hartmann, M., \& Honneth, A. (2006). Paradoxes of capitalism. Constellations, 13(1), 41-58. doi:10.1111/j.1351-0487.2006.00439.x.

Honneth, A. (1995). The struggle for recognition: The moral grammar of social conflicts. Cambridge, MA: The MIT Press.

Honneth, A. (2003). Redistribution as Recognition: a Response to Nancy Fraser. In: N. Fraser \& A. Honneth (Eds.), Redistribution or Recognition: a Political-Philosophical Exchange. 1.ed, Cap. 2. P 110-160. London, United Kingdom: Verso.

Melo, R. S. (2013). Teoria Crítica de Axel Honneth: Reconhecimento, Liberdade e justiça. São Paulo, Brasil: Editora Saraiva.

Mendes, R. M., Nunes, M. L., Pinho, J. A., \& Gonçalves, R. B. (2018). Organization of rehabilitation care in Portuguese intensive care units. Revista Brasileira de Terapia Intensiva, 30(1), 57-63. doi:10.5935/0103-507x.20180011.

Miranda, S. F. (2011). A questão do reconhecimento: Axel Honneth e a atualização do modelo conceitual hegeliano da psicologia social de George Herbert Mead. In V. Schmitz, Axel Honneth e a teoria crítica do reconhecimento (pp. 135-145). Rio de Janeiro, Brasil: Centro Edelstein de Pesquisa Social. Retrieved from http://books. scielo.org/id/xg9wp/pdf/spink-9788579820571.pdf

Paula, E. A., \& Amaral, R. M. (2019). Atuação interdisciplinar em grupos de qualidade de vida para pacientes com lesôes por esforços repetitivos/distúrbios osteomusculares relacionados ao trabalho - LER/DORT. Revista Brasileira de Saúde Ocupacional, 44(e5), 1-10. doi:10.1590/2317-6369000013119.
Risjord, M. (2013). Nursing and human freedom. Nursing Philosophy, 15(1), 35-45. doi:10.1111/nup.12026

Rocha, S. A., Avila, M. A. G., \& Bocchi, S. C. M. (2016). Influência do cuidador informal na reabilitaçáo do idoso em pós-operatório de fratura de fêmur proximal. Revista Gaúcha de Enfermagem, 37(1), e51069. doi: 10.1590/1983-1447.2016.01.51069.

Schoeller, S. D., Martins, M. M., Ribeiro, I., Lima, D. K., Padilha, M. I., \& Gomes, B. P. (2018). Breve panorama mundial da enfermagem de reabilitação. Revista Portuguesa de Enfermagem de Reabilitação, 1(1), 06-12. doi: 10.33194/rper.2018.v1.n1.01.4388

Sena, M. C., Bastos, P. R., Marques, H. R., \& Silva, G. (2018). Reflexôes sobre o direito à educação da pessoa com deficiência. MultiTemas, 23(55), 213-227. doi:10.20435/multi.v23i55.1869

Spinelli, L. (2016). Amor, direito e estima social: Intersubjetividade e emancipação em Axel Honneth. Latitude, 10(1), 84-111. doi:10.28998/2179-5428.20160104

Taylor, C. (2014). Hegel the modern society ( $1^{\text {st }}$ ed. electronics). Mexico, MX: Fund of Economic Culture.

Whelton, B. J. (2015). Being human in a global age of technology. Nursing Philosophy, 17(1), 28-35. doi: 10.1111/nup.12109

Wernet, M., Mello, D. F., \& Ayres, J. R. (2017). Recognition in Axel Honneth: Contributions to Research in Health Care. Texto \& Contexto Enfermagem, 26(4), e0550017. doi:10.1590/0104070720170000550017 